\title{
The Buddhist Philosophical Conception of Intersubjectivity: an Introduction
}

\author{
Roy Tzohar $^{1}$
}

Published online: 10 April 2019

(C) Springer Nature B.V. 2019

This paper serves as a retrospective introduction to a series of four tightly connected articles $^{1}$ published over the course of several issues in SOPHIA, all of which arose from a panel on the Buddhist Philosophical Notion of Intersubjectivity at the Yogācāra Studies Unit of the Annual Meeting of the American Academy of Religion (AAR, Atlanta, 2015). The growing online access to academic journals seems increasingly to obviate the need to group thematically related articles in a special issue, but nonetheless, readers may wish for some guidance regarding the editorial reasons for grouping them in a series, the common concerns they address, and the ways in which they relate to each other. This brief introduction therefore outlines a possible framework for approaching these papers, and suggests a particular order in which they can be most profitably read.

The philosophical engagement with the issue of intersubjectivity-i.e., the shared nature of our experiences, in particular of the external world - has evident significance for an array of Buddhist concerns. Intersubjective experience is of interest not just for its role in bridging the self and others, but also because it allows (and for the philosophical realist, indeed reaffirms) an emergent notion of objectivity. Viewed on the one hand against the background of the Buddhist metaphysics of momentariness and causality, the critique of the self, and nominalism, and on the other hand in light of the Buddhist emphasis on the practical and social role of the Sangha and of meaningful salvific discourse, intersubjectivity poses a particularly tenacious explanatory challenge for Buddhist schools of thought. It is a curious fact, then, that despite the significance of

\footnotetext{
${ }^{1}$ Guest edited by Roy Tzohar and Jake Davis, and include: Roy Tzohar, "Imagine Being a Preta: Early Indian Yogācāra Approaches to Intersubjectivity" Sophia 56 (2017): 337-354; Catherine Prueitt, "Karmic Imprints, Exclusion, and the Creation of the Worlds of Conventional Experience in Dharmakīti's Thought," Sophia 57 (2018): 313-335; Sonam Kachru, "Ratnakīrti and the Extent of Inner Space: An Essay on Yogācāra and the Threat of Genuine of Solipsism," Sophia 58 (2019): https://doi.org/10.1007/s11841-019-0707-8; Jay L.

Garfield, "I Take Refuge in the Sangha. But how? The Puzzle of Intersubjectivity in Buddhist Philosophy, Comments on Tzohar, Prueitt, and Kachru,” Sophia 58 (2019): https://doi.org/10.1007/s11841-019-0708-7.
}

A comment to this article is available at https://doi.org/10.1007/s11841-019-0724-7.

Roy Tzohar

roy.tzohar@gmail.com

1 Tel Aviv University, Tel Aviv, Israel 
this topic and its relevance to the Buddhist understanding of personal identity, otherness, and the nature of the life-world, it has received relatively little explicit attention in either Buddhist philosophical writing (see Garfield's response paper on this point) or contemporary scholarship. As a corrective, the AAR panel and the set of articles that ensued from it - by Kachru, Prueitt, and Tzohar, and a response paper by Garfield addressed this theme from various angles. The overarching question at the background of the discussion was whether there is a uniquely Buddhist conception of intersubjectivity, and if so what it entails and what are its expressions in the Buddhist philosophical conception of experience, language, and the life-world.

Aiming to situate these questions within a concrete and continuous intellectual and historical context, the papers focus on the Yogācāra-Vijñānavāda tradition as a case study. Taken together, they provide a diachronic account of the development of this particular Buddhist approach to the topic, by tracing continuity, disruption, and innovation as the outcomes of shifting intellectual agendas in the works of Vasubandhu and his commentators (Tzohar), Dharmakīrti's thought (Prueitt), and Ratnakīrti's response (Kachru).

While they are attuned to differences between the respective accounts of these thinkers, the papers all seem to suggest certain overlapping concerns. These concerns, and the ways in which they were addressed by the Buddhist thinkers, are spelled out and assessed in Jay Garfield's response paper, "I Take Refuge in the Sangha. But how? The Puzzle of Intersubjectivity in Buddhist Philosophy Comments on Tzohar, Prueitt, and Kachru." The most common concern, pointed out by Garfield, has to do with the need to account for and justify the possibility of intersubjective experiences under a view of phenomena as mind-dependent, and it is framed - not unlike the way it appears in the Western philosophical tradition - in terms of the perennial debate between the realist and the idealist. Another major if more subtle concern has to do with the question of meaning - in both the perceptual and the linguistic communicative realm - and how it can be construed intersubjectively so as to allow for shared perceptual content and efficacious actions, to account for successful and meaningful language use (in the constitution of norms), and to avoid the pitfalls of solipsism on the one hand or incommensurability on the other.

Dealing broadly with these concerns within the context of each thinker, the papers before us reveal the way in which intersubjectivity branches off into a range of fundamental questions in Buddhist metaphysics, epistemology, and philosophy of mind and language, all of which are deeply grounded in particular Buddhist conceptions - of, for instance, cosmology, the category of species, the concept of mind and the operation of language. In this respect, the emergent collective account of Buddhist intersubjectivity serves as a step toward much needed conceptual groundwork regarding this notion in its original context, that is, groundwork that takes into account the meaning of specific specialized terms and categories involved in this notion, and the way in which it conveys a complex set of cultural preferences and doctrinal premises.

My own paper in the series, "Imagine being a Preta: Early Indian Yogācāra Approaches to Intersubjectivity," deals with the early Yogācāra strategies for explaining intersubjective agreement under a "mere representations" view. Thus, this paper presents the foundational tradition to which the other Buddhist thinkers react, and in this respect sets down the terms of the discussion taken up in the other three papers. Examining Vasubandhu's, Asanga's, and Sthiramati's uses of the example of intersubjective agreement among the hungry ghosts (pretas) - an agreement explained by 
appeal to a shared karma-I demonstrate that the Yogācāra arguments should be understood as an ironic inversion of the realist premise; in other words, as showing that intersubjective agreement not only does not require the existence of external mindindependent objects, but in fact is incompatible with their existence. Under this account, I argue, intersubjectivity is not only possible under a "mere-representation" view but necessary for the coherence of the Yogācāra view. As Garfield observes about this Yogācāra reasoning, "it is the fact that external objects are imagined not by a single mind, but by many... that gives the argument its force, for that enables genuinely alternative realities to be compared to one another to demonstrate that reality, not hallucination, is mind-dependent" (Garfield, https://doi.org/10.1007/s11841-019-0708-7).

My paper goes on to explicate the emergent Yogācāra understanding of the lifeworld - as the outcome of the shared karma of all its beings - as a realm that is understood in terms of the self and others' shared engagement in a common world. This has some affinity with the way the contemporary phenomenological tradition conceives of intersubjectivity, but unlike the phenomenological account, the Yogācāra takes the first-person perspective to be a product rather than the enabling condition of this engagement. Among the ramifications of this reluctance to privilege the first-person perspective, I argued, is a radical revision of the "shared" and "private" distinction as it is used with respect to experiences, both ordinarily and philosophically.

Exploring the later development of these themes from the perspective of Buddhist philosophy of language is the focus of Catherine Prueitt's paper "Karmic Imprints, Exclusion, and the Creation of the Worlds of Conventional Experience in Dharmakīrti's Thought." The early Yogācāra attempt to uphold and justify intersubjectivity by appeal to shared karmic imprints ( $v \bar{a} s a n \bar{a})$ is the starting point for Prueitt's paper, which explicates the way in which this strategy is used by Dharmakîrti (fl. c. 550-650 C.E.) to explain the absence of universals under his theory of apoha. While she traces the continuity between these two accounts, Prueitt points out important points in which Dharmakīrti departs from the early Yogācāra reasoning. For Dharmakīrti, she suggests, intersubjectivity was important not so much for defending a view of phenomena as mind-dependent but insofar as it was involved in the more fundamental question of how shared meaning - in its most fundamental function as concept formation - may be construed and normatively applied.

Prueitt's paper demonstrates how, with the premise of the non-existence of universals, Dharmakirti explains concept formation by tracing concepts ultimately to the mechanism of karmic imprints (which in turn are understood to be developed over countless lifetimes and continuously and recursively reshaped by ongoing actions). Couched in terms similar to those of the early Yogācāra account, according to Dharmakirti, the extent to which individuals experience themselves as acting within a shared world (or not) depends on these imprints. Whatever is shared-manifested in terms of similar sensory capacities, habits, and aims - allows in turn for the judgment of sameness, that is, forms the basis for selectively collecting certain particulars (taking them as if having the same effects) under a single concept.

Prueitt's argument goes on to show that Dharmakīrti's appeal to karmic imprints also allows him to meet the critique (both traditional and modern) that his denial of the reality of the subject/object duality is incompatible with his theory of apoha. She concludes that Dharmakīrti's reliance on karmic imprints on two distinct levels - one within the conventional world (i.e., concept formation), and one that constitutes the 
conventional world (i.e., the subject/object duality) — provides a round and complete account of intersubjectivity without relying on universals.

Proceeding to examine the changing conception of intersubjectivity within changing theories of mind in the Yogācāra-Vijñānavāda tradition, Sonam Kachru's paper "Ratnakīrti and the Extent of Inner Space: An Essay on Yogācāra and the Threat of Genuine of Solipsism" traces the outlines of what may be described as a paradigm shift in the tradition with respect to the conceptual foundations of intersubjectivity.

The paper achieves this by focusing on the response by Ratnakirti (990-1050 C.E.) to Dharmakirti's attempt to defuse the threat of epistemological solipsism, with particular attention to the former's sensitivity to the conceptual preconditions of this problem, and to the ways in which his conclusions differ from Dharmakīti's.

According to Kachru's analysis, Ratnakīrti's critique, in essence, is that Dharmakīrti overlooks the fact that in framing the problem he is helping himself to an equivocation between two distinct concepts of mind (which, however, remain inactive in forming his solution to the problem). The first is a notion of mind that emerges out of our ordinary linguistic practices, and the second, a phenomenological concept of mind as phenomenal presence. Given the latter conception of mind, so goes Ratnakīrti's argumentwhich, as Garfield notes, has interesting affinities with similar treatments of the problem of other minds in contemporary philosophy of mind and language, beginning with Wittgenstein - there is indeed no justification for applying the concept of "other minds," but neither are there any grounds to speak of "one's own mind" (because insofar as the phenomenological concept of mind is experienced as such, we have no room to meaningfully ask whether there is only one mind or many). Kachru's essay concludes by considering which of the different ways we find in the YogācāraVijñānavāda tradition to assuage epistemological solipsism we have reason to prefer, thereby exploring the impact these various theories of mind have had on the changing place of intersubjectivity within that tradition.

Publisher's Note Springer Nature remains neutral with regard to jurisdictional claims in published maps and institutional affiliations. 